\title{
Perinatal ethyl alcohol effects on the development of cerebellar cortex in albino rat
}

\author{
Allam A. ${ }^{1 \star}$, Abdul-Hamid M. $^{2}$, Allam G. $^{2,3}$, Al-hroob $A^{4}$, Ibraheem $G^{1}$ and Alsubaie $M^{5}$ \\ ${ }^{1}$ Department of Zoology, Faculty of Science, K,ing Saud University, Saudi Arabia. \\ ${ }^{2}$ Department of Zoology, Faculty of Science, Beni-Suef University, Egypt. \\ ${ }^{3}$ Department of Microbiology, College of Medicine and Medical Sciences, Taif University, Taif, Saudi Arabia. \\ ${ }^{4}$ Department of Biological Sciences, Al-Hussein Bin Talal University, Jordan. \\ ${ }^{5}$ King Saud University, College of Pharmacy, Riyadh, Saudia Arabia.
}

Accepted 6 May, 2013

\begin{abstract}
The present study aimed to show the effect of chronic low dose of ethyl alcohol on the cerebellar neurons in rat newborns. After birth, the newborns were divided into five groups: A, B, C, D and E. Group $A$ is normal newborns while groups $B, C, D$ and $E$ are treated groups. The present results confirmed that ethanol during pregnancy has adverse effects on the neurogenesis of cerebellar cortex. These effects extended to the postnatal stages. The treated groups showed cell loss represented by neurocyte chromatolysis and pyknosis. Alcohol affects the dendritic tree of Purkinje cells so it was reduced in groups $B$ and $C$, but was moderate in size in groups $D$ and $E$. The normal Purkinje cells were deeply stained; this reflects the high amount of Nissl granules if compared with other treated groups. In group B, some of the detected neurons were degenerated. In group C, most of neurons were pale at days 7 and 21, while they were moderately-stained in groups $D$ and $E$.
\end{abstract}

Key words: Alcohol, cerebellum, Purkinje cells, newborns, histopathology, ultrastructure.

\section{INTRODUCTION}

Alcohol is now widely recognized as a neuroteratogen (Thomas et al., 1998; Maier and West, 2003; Sandra and Michael, 2003; Huang et al., 2012). Some women who drink heavily during pregnancy may deliver children who may be diagnosed with fetal alcohol syndrome (Jones and smith, 1973; Spottiswoode et al., 2011), or their children may be afflicted with alcohol-related deficits, such as neuroanatomical malformations (Clarren et al., 1978; Reneau et al., 2011), congenital dysfunction (Coles et al., 1991), or other behavioural disorders (Ernhart et al., 1985). The extent to which the offspring of mothers drinking during the pregnancy are diagnosed with an alcohol-related neurological disorder may be related to several factors, such as the pattern of alcohol consumption (Bonthius et al., 1992; Spottiswoode et al., 2011), poly-drug use (Richardson et al., 1995) or duration of drinking (Maier and West, 2001).
Animal research indicated a multifactorial mechanism of the teratogenicity of alcohol resulting from nutrient deficiencies, fetal hypoxia alterations in enzyme activities and cell functions (Hankin et al., 2000). Ethanol may also impair lactation performance, mammary gland function and newborns growth (Ludena et al., 1983). Moreover, chronic alcohol administration to the lactating rats also affects suckling-induced prolactin release (Tavares et al., 1999; Luisa et al., 2001).

The cerebellum has received a great deal of attention from neuroscientists in order to understand its basic organization, neural circuitry and development Bondok et al., 1991; Mohammed et al., 1997). It was found that the continuous ethyl alcohol ingestion at high doses has risk effects on the cerebellum and its neurons especially Purkinje cells (Fitzgerald et al., 2011; Hill et al., 2011; Heaton et al., 2012). The principal aim of this study was 
to determine the effect of low dose of ethyl alcohol on the development of some cerebellar neurons in the rat newborns between Days 7 and 21. This is monitored by histological and ultrastructural studies on control and treated newborns.

\section{MATERIALS AND METHODS}

\section{Drug used}

Pure ethyl alcohol was purchased from Reideld-de-Haun Company (Germany) at purity of $100 \%$. Alcohol was diluted and orally administrated to non-anesthetized pregnant females by gastric intubation every day from the day 7 of gestation in a dose of $0.5 \mathrm{ml}$ of $33 \%$ ethyl alcohol, which is equivalent to $700 \mathrm{mg} / \mathrm{kg}$. This dose is low if compared to the doses used by Maier and West (2001), which were $2.5,4.5$ and $3.6 \mathrm{~g} / \mathrm{kg} /$ day, or to the dose $(6.6 \mathrm{~g} / \mathrm{kg} /$ day $)$ which was used by Thomas et al. (1998).

\section{Animal dosing schedule}

This study has used a total of ninety albino rats (Rattus norvegicus). Seventy five mature virgin females and 15 mature males weighing 140 to $150 \mathrm{~g}$ were purchased from the Organization for Vaccine and Biological Preparations (Helwan laboratory farms, Egypt). Animals were marked, housed 3 per cage and fed standard rodent pellet diet manufactured by the Egyptian Company for Oil and Soap (Cairo, Egypt). Tap water was given ad libitum. Daily examination of vaginal smear of each virgin female was carried out to determine the estrous cycle. Estrous females exhibited the presence of cornified cells in vaginal smear. Mating was done by overnight housing of 2 pro-estrous females with one male in separate cages. The presence of sperm in vaginal smear determined the day 0 of gestation.

The newborns were divided into five groups as follow: Group A, untreated newborns (control); group $B$, the mothers of these newborns were given alcohol from day 7 of gestation till day 21 after birth; group $\mathrm{C}$, the mothers of these newborns received alcohol from day 7 of gestation and still fostered their newborns; group D, the newborns of treated mothers were transferred at birth to be breastfed by untreated normal mothers (normal surrogate mothers) for 21 days; group $\mathrm{E}$, the newborns of normal mothers were transferred at birth to be breastfed by females that were given alcohol every day (treated surrogate mother) for 21 days.

\section{Histological preparations for light microscope}

On postnatal days 7 and 21, 5 of the newborns from each group were sacrificed. Segments of the cerebellum were fixed in $20 \%$ buffered formalin ( $\mathrm{pH} \mathrm{7.4)}$ for $48 \mathrm{~h}$. The tissue was dehydrated in ethyl alcohol followed by two changes of xylene. The tissue was impregnated in paraffin wax and then embedded in paraffin wax. Sections $(5 \mu \mathrm{m})$ were cut, de-waxed, hydrated and stained in Mayer's haemalum solution for $3 \mathrm{~min}$. The sections were stained in Eosin for $1 \mathrm{~min}$, washed in tap water and dehydrated in ethanol as described earlier. Haematoxylin and Eosin stained sections of cerebellum were prepared according to the method of Mallory (1988).

\section{Toluidine blue stain}

The prepared serial sections of cerebellum at days 7 and 21 were de-waxed then transferred to $95 \%$ alcohol. The slides were put in alcoholic colophonium solution for $5 \mathrm{~min}$ (10 g colophonium in 105 $\mathrm{ml} 95 \%$ alcohol) followed by two changes of $95 \%$ alcohol each for 3 min. Slides were stained in toluidine blue $0.1 \%$ for $30 \mathrm{~s}$, and then were differentiated in a mixture of $10 \%$ analine and $95 \%$ alcohol, clearing in different changes of Cajput oil, and finally mounting in Canada balsam.

\section{Golgi-Copsch technique}

The cerebellum of each group was cut into slices at day 21 . The slices were placed in $4: 1$ mixture of $5 \%$ potassium dichromate and concentrated formaldehyde $(40 \%)$ for 4 days. The slices were transferred to $3.6 \%$ potassium dichromate for 4 days. They were washed in 0.75 sliver nitrate and then placed in the same solution for 4 days. The last two steps were repeated twice. The slices were dehydrated then placed in xylene for $1 \mathrm{~h}$. Embedding process was made in paraffin wax. Serial sections were made at $40 \mu \mathrm{m}$. The sections were de-waxed by using xylene. The sections were mounted in Canada balsam (Tombol, 1966).

\section{RESULTS}

At day 7 , the thickness of the external granular layer was wide in groups $A, D$ and $E$ (Figure 1a, $d$ and e), but appeared as thin layer in group C (Figure 1c) and small in group $B$ (Figure 1b).

In group $A$ at day 21 , the external granular layer was absent in some regions but still represented in the others by a single row of cells (Figure $2 a$ and $b$ ). In the treated groups, this layer was represented in all examined regions and appeared as two rows of cells in most regions especially in groups $B$ and $C$ (Figure $2 c, d$, e and f).

The normal molecular layer of all the treated groups varied in width when compared with the normal group (Figure $1 b, c, d$ and e). In groups A and D, the molecular layer was increased in width at day 21 , while it was narrow in groups $B$ and $C$ and moderate in width in group $\mathrm{E}$ (Figure 2a, b, c, d and e). The vertically oriented spindle-shaped cells were fewer in group $A$ than in the other treated groups (Figure 2a, b, c, d and e). Neurocyte chromatolysis was detected in the molecular layer neurons of groups $B$ and $C$, while pyknotic neurons were found in group $E$ (Figure $2 b, c, d$ and e). The molecular layer neuron density was higher in group $A$, moderate in groups C, D and E and lower in group B (Figure 2a, b, c, d and e).

The normal Purkinje cells at D7 were visible and arranged in a single row, while in the other groups these cells were arranged in more than one row (Figure 1a, b, $\mathrm{c}, \mathrm{d}$ and $\mathrm{e})$. In the normal group, Purkinje cells appeared large and spherical in shape. There were many processes that arose from all sides of the cell body (Figure 1a). In groups $D$ and $E$, Purkinje cells were moderate in size (Figure $2 d$ and e), while in groups $B$ and $\mathrm{C}$, they appeared small in size (Figure 1b, c, $d$ and e).

At day 21, Purkinje cells were arranged in a single row in both normal and treated newborns to form a Purkinje cell layer. In normal newborns, Purkinje cells appeared 


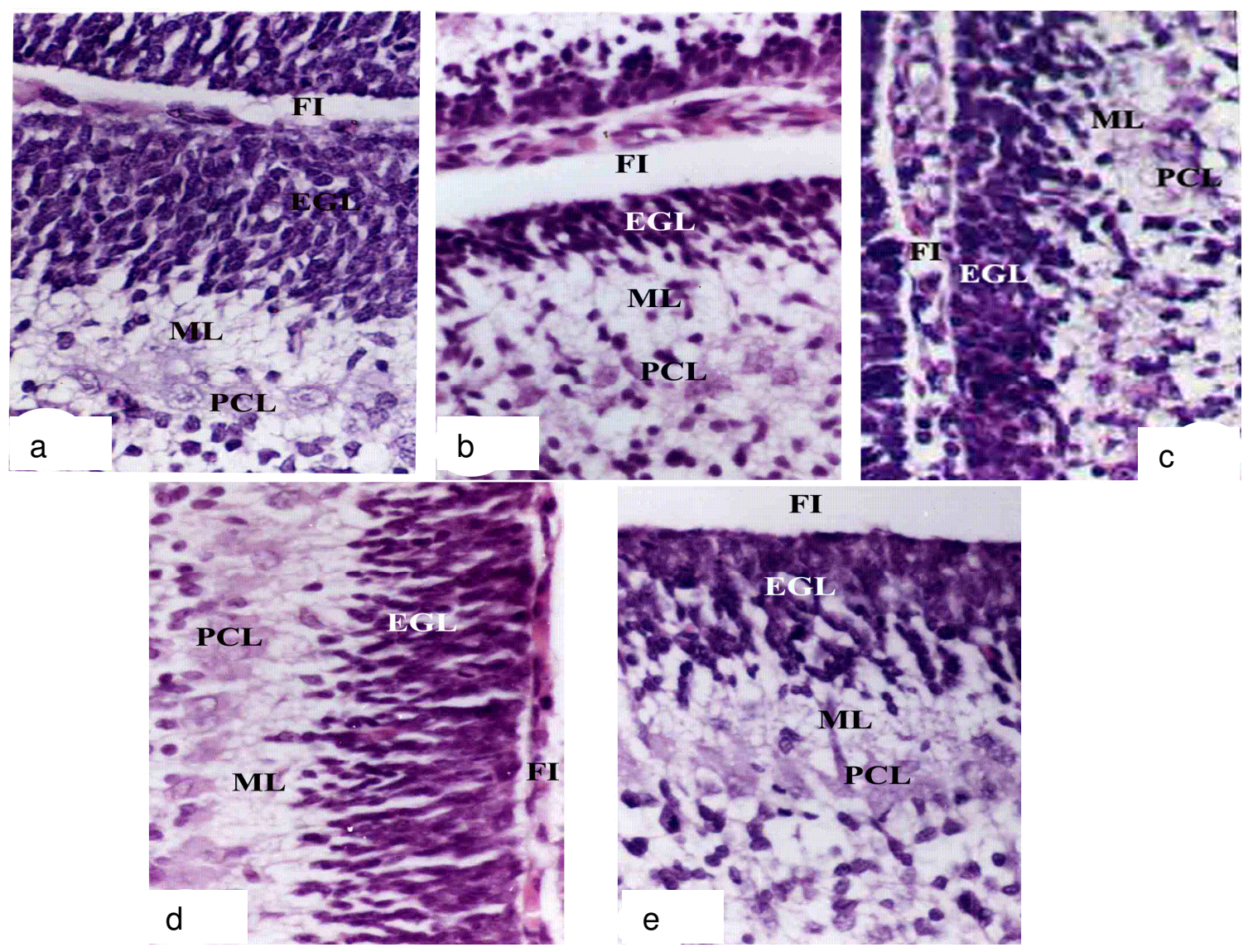

Figure 1. Sagittal sections in the cerebellar cortex at day 7 show the external granular layer (EGL), fissure (FI) and Purkinje cell layer (PCL). Group A (a), Group B (b), Group C (c), Group D (d) and Group E (e) (Hand E, x400).

pear-shaped, while in the treated groups these cells were more spindle-shaped and small (Figure 2a, b, c, d and e). The lateral processes disappeared and the apical processes formed the permanent dendritic tree. In group $\mathrm{B}$, there was abnormality in the distribution of Purkinje cells where the distance between them was wide reflecting the low number of these cells (Figure 2b).

At day 7 , the internal granular layer was sparsely populated and thin in group A (Figure 1a), but less defined in the treated groups (Figure 1b, c, d and e). At day 21, the thickness of this layer was variable. The thickness of internal granular layer was wide in groups $A$ and $D$ than in groups $\mathrm{B}, \mathrm{C}$ and $\mathrm{E}$ (Figure $2 \mathrm{a}, \mathrm{b}, \mathrm{c}, \mathrm{d}$, and $\mathrm{e}$ ). The density of the internal granular layer cells is high in group A than in the treated groups. It became well differentiated and the granular cells became numerous and arranged in groups. The Golgi cells appeared large in size and occupied the upper region of the internal granular layer (Figure 2a, b, c and e).

The density of the Nissl granules was increased with time in the normal newborns. The Nissl granules were distributed in the cytoplasm around the nucleus and in the proximal parts of the dendrites. At day 7, in group A, Purkinje cells were deeply-stained (Figure $3 a$ ), while in groups $D$ and $E$ they were moderately stained (Figure $3 d$ and $e$ ) and pale-stained in groups $B$ and $C$ (Figure $3 b$ and c).

At day 21, the normal Purkinje cells were intenselystained with clear apical dendrites (Figure 4a). In groups $C, D$ and $E$, Purkinje cells appeared moderately-stained (Figure 4c, d and e). In group B, some degenerated Purkinje cells were observed (Figure $4 b$ ).

At day 21, the Purkinje cells in all groups appeared possessing one or two main apical dendrites. The dendrites arise as a main process from the upper end of the cell body, then branches and extends through the molecular layer. This main dendrite repeatedly branch to form a large and fully formed dendritic arborization. The arborizations are formed from lateral processes that emerged from the main dendrite. The Purkinje cells arborizations that could be traced in the molecular layer were well-developed in group A (Figure 5a), but moderately developed in most cells of groups $D$ and $E$ (Figure $5 \mathrm{~d}$ and e). In addition, the arborizations nearly disappeared in most cells of groups B and C, especially in group $B$. The main dendrites were still present and extended in the molecular layer. In groups B and C, the Purkinje cells bodies lost their pear-shaped and became 


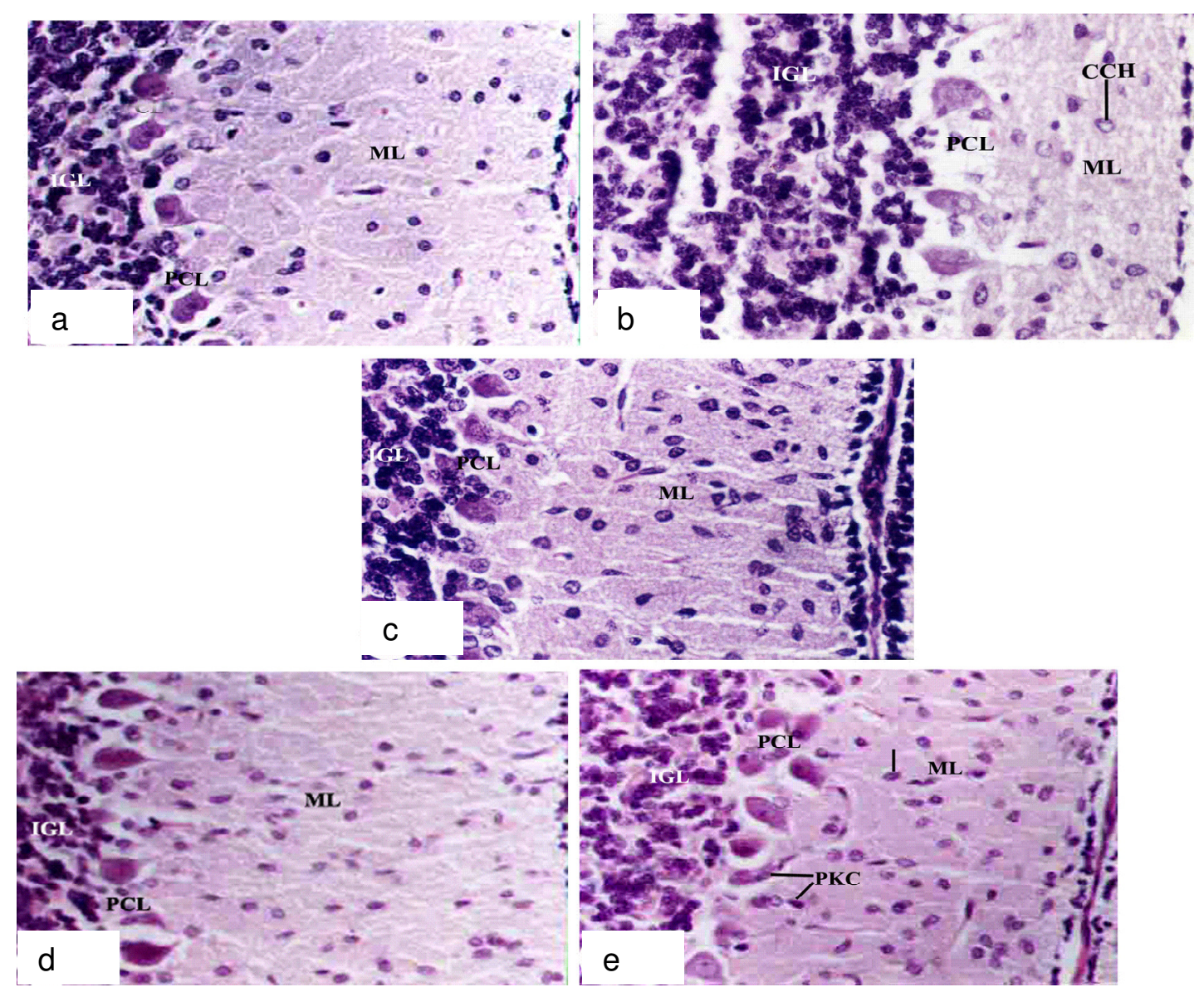

Figure 2. Sagittal sections in the cerebellar cortex at day 21 show the external granular layer (EGL), the molecular layer (ML), the internal granular layer (IGL), Purkinje cell (PC), neurocyte chromatolysis $(\mathrm{CCH})$ and pyknotic cell (PKC). Group A (a), Group B (b), Group C (c), Group D (d) and Group E (e) (Hand E, $\mathrm{x} 400)$.

more elongated and flattened (Figure $5 \mathrm{~b}$ and $\mathrm{c}$ ).

\section{DISCUSSION}

The present results confirmed that ethanol induces neurohistological malformations in the cerebellar cortex cells; retarded maturations and differentiation of neurons in addition to neuronal loss. The external granular layer was still represented at day 21 by one row of cells or absent in some regions. The disappearance of this layer was attributed to the migration of its cells, which in turn increased in the width during the resorption of the external granular layer (Bondok et al., 1991).

The external granular layer was the external germinal layer which generates the granular cells, then the cells start to migrate through the Purkinje cell layer at postnatal day 4 to form the internal granular layer (Marcelo and Fahad, 2002). Therefore, the internal granular layer will be affected by the aberration in the external granular layer. This layer was variable in its thickness between groups at days 7 and 21 . The pre- and post-natal chronic alcohol administration delays the proliferations of the cells of this layer (Saleh et al., 1993; Idrus and Napper, 2012). At day 7, this layer was thin due to low rate of cell division that resulted from prenatal alcohol exposure and bad maternal behaviour (Miller, 1996). At day 21 , this layer was thick in groups $B$ and $C$ and thin in groups $D$ and $E$ due to the retardation in cells migration of this layer as described by Marcelo and Fahad (2002) and lqbal et al. (2004).

In this study, the internal granular layer of the treated groups was undifferentiated from the white matter until day 7. Saleh et al. (1995) reported that the granular layer was still undemarcated from the white matter until day 10 in alcohol-exposed rat newborns. The present electron microscopical study of the treated groups showed degenerated cells in the granular layer due to alcohol exposure. This result is in accordance with Behave and Hoffmann (1997) and Heaton et al. (2000) who reported that alcohol may induce apoptosis in granular cells of cerebellum. Moreover, Tavares and Paula-Barbosa (1986) and Heaton et al. (2012) count the number of granular cells per unit volume in both the normal and ethanol treated 

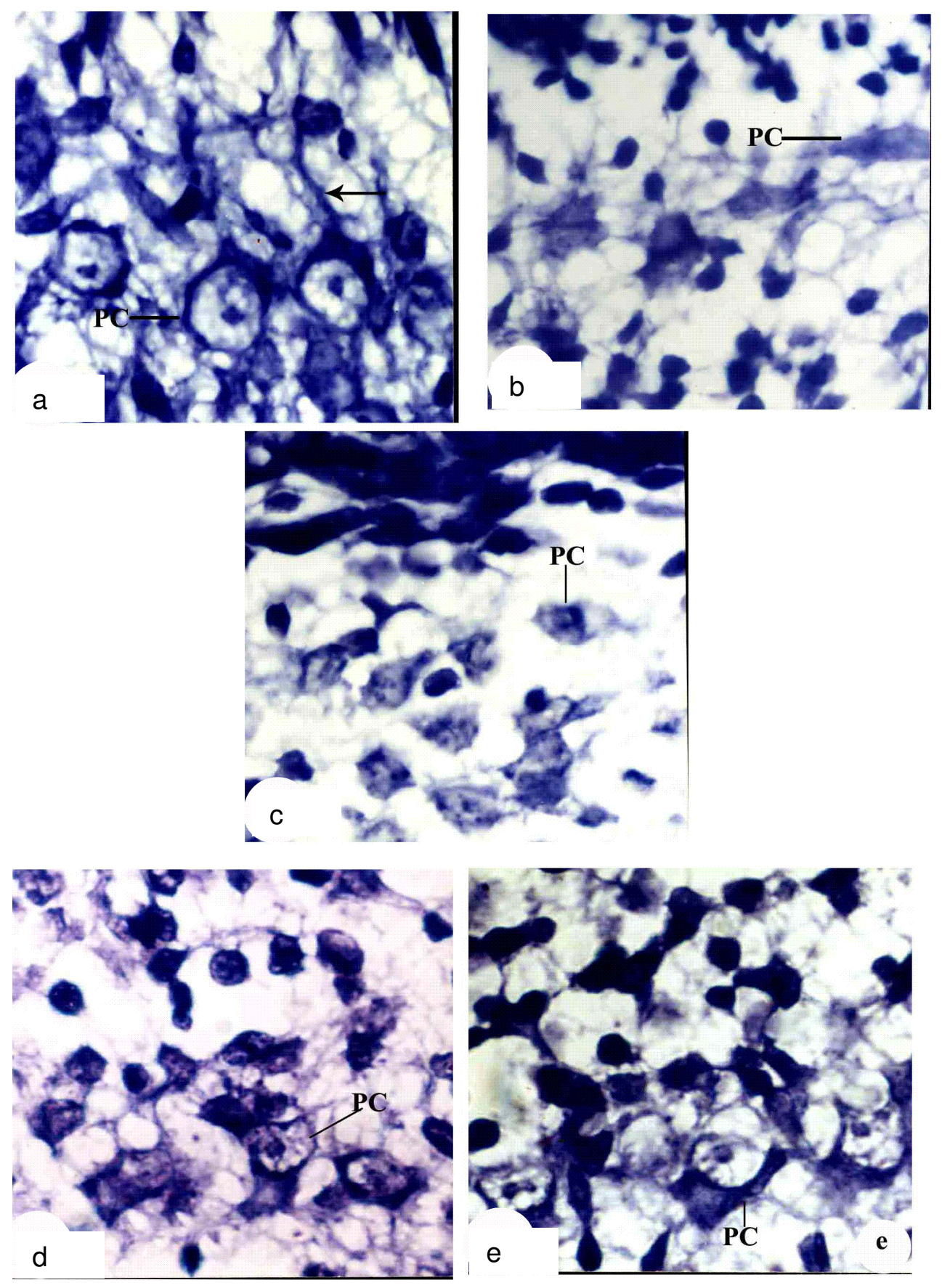

Figure 3. Sagittal sections in the cerebellar cortex at day 7 show the distribution of Nissl granules in Purkinje cells (PC).

The arrow refers to the apical dendrites. Group A (a), Groups B (b), Groups C (c), Groups D (d) and Groups E (e) (Toluidine blue stain, x1000).

rats and found that alcohol exposure increase the granular cell loss. The width of this layer in the treated groups was narrow which reflects the brain restriction and microcephaly (Luke, 1990; Sulik, 2005).

In normal rat newborns, the molecular layer increased in thickness at days 7 and 21. The molecular layer width was depending on the number of its neurons and size of
Purkinje cell arborization (Bondok et al., 1991). Therefore, the size of the molecular layer at day 21 was narrow in groups $\mathrm{B}$ and $\mathrm{C}$ and moderate in groups $\mathrm{D}$ and $\mathrm{E}$. West et al. (2001) and Idrus and Napper (2012) reported that alcohol mediates cells loss especially Purkinje cells. Griffin et al. (1977) recorded that malnutrition induces aberration in Purkinje cells dendrites. These results 

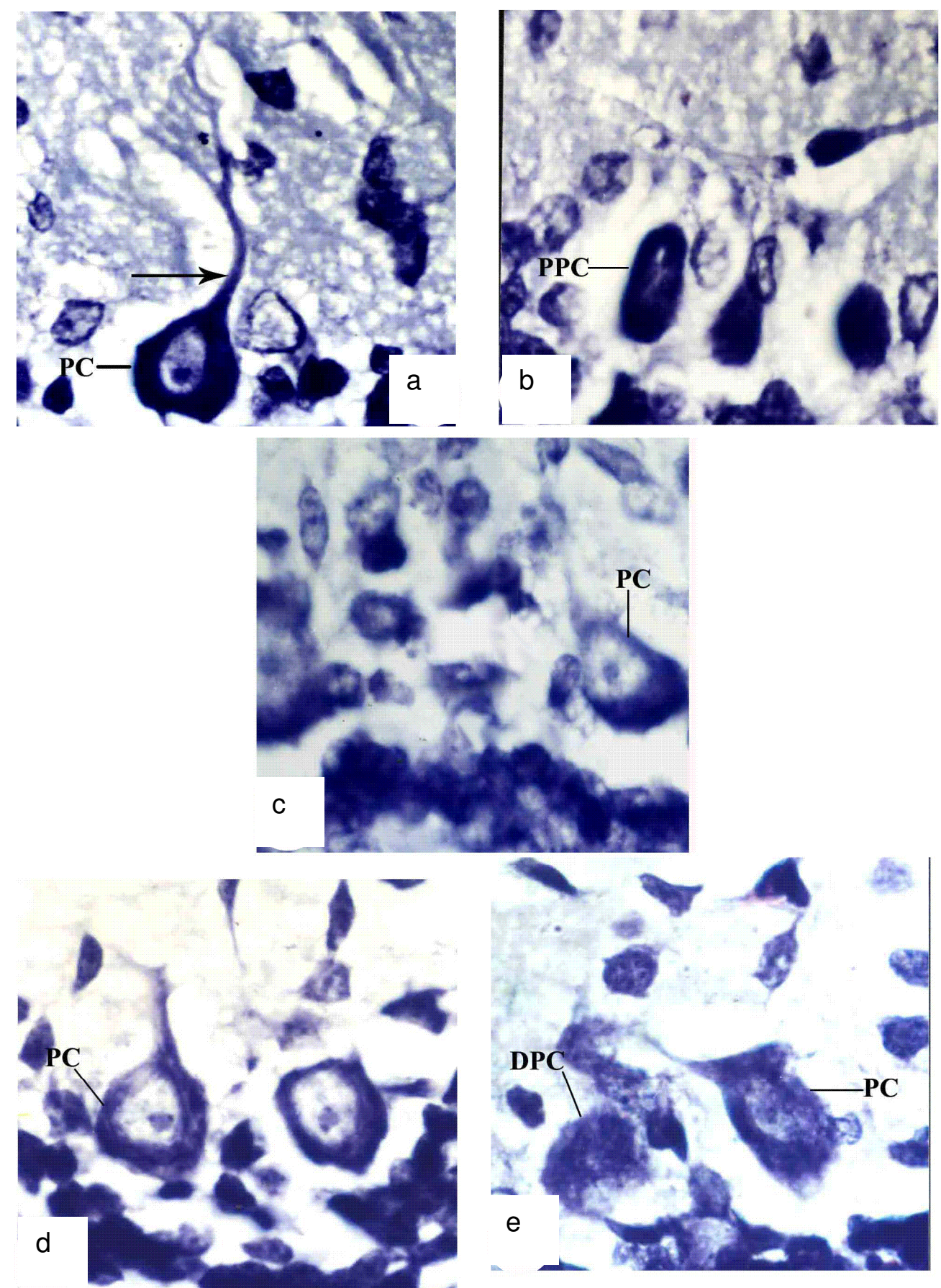

Figure 4. Sagittal sections in the cerebellar cortex at D21 show the distribution of Nissl granules, degenerated Purkinje cells (DPC), Purkinje cells (PC), Pyknotic Purkinje cells (PPC). The arrow refers to the apical dendrites. Group A (a), Group B (b), Group C (c), Group D (d) and Group E (e) (Toluidine-blue stain, x1000)

confirmed that the width of molecular was narrow in treated groups. The present reduction in the width of molecular layer in the treated groups reflected the microcephaly, which was caused by the action of alcohol (Luke, 1990; Maier et al., 1997; Sulik, 2005).

At day 7 , Purkinje cells are arranged in one row in the present normal newborns. These cells are arranged to form Purkinje cell layer at day 21 at the junction between the molecular and internal granular layer; this result is in agreement with Bondok et al. (1991) and Saleh et al. (1993). Altaman and Winfree (1977) explained the arrangement in a single row due to the pressure exerted 

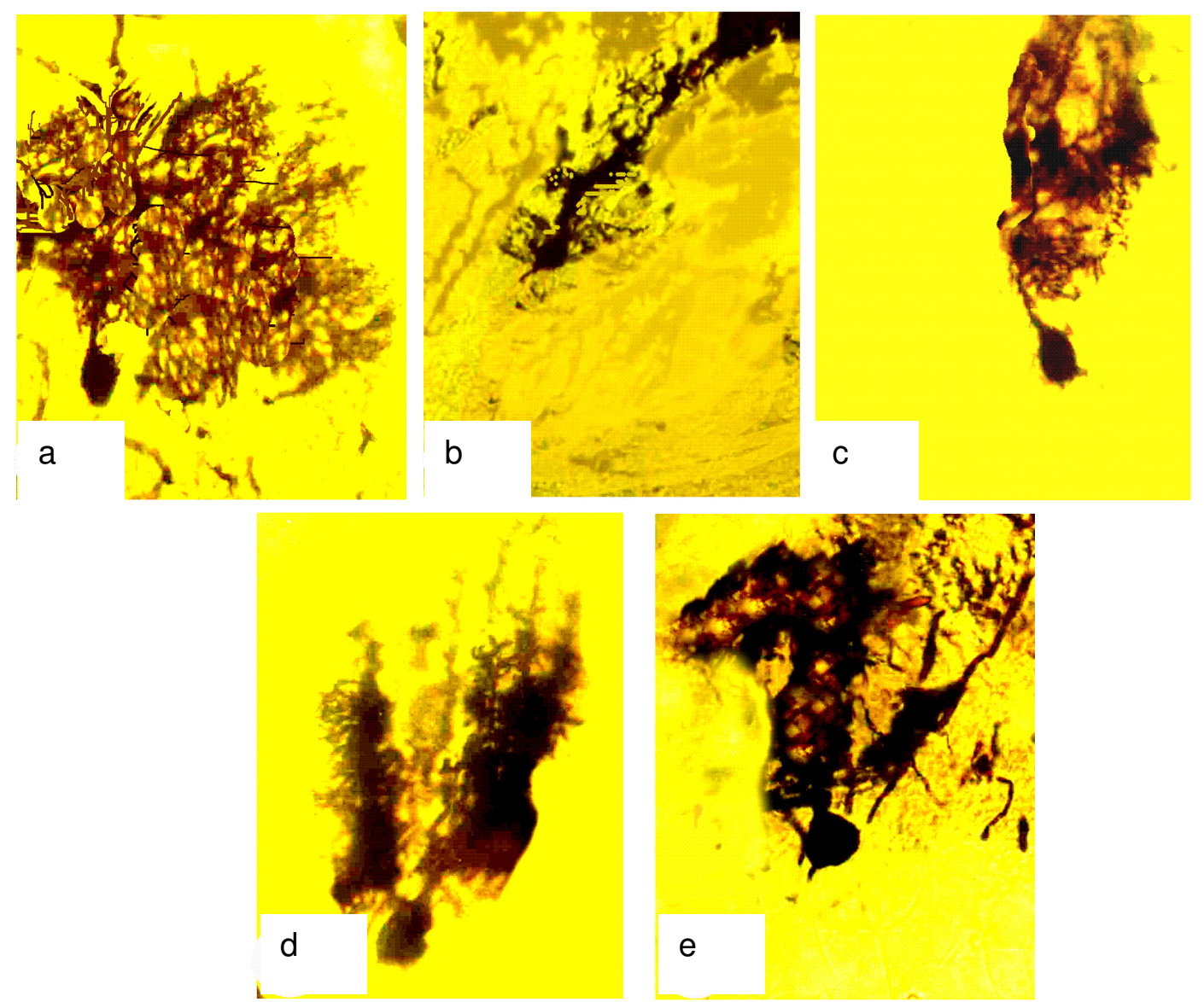

Figure 5. Sagittal sections in the cerebellar cortex at day 21 show the Purkinje cell (PC) dendrites in the experimental Group A (a), Group B (b), Group C (c), Group D (d) and Group E (e) (Golgi-Copssch stain, $\mathrm{x} 200)$.

on the growing Purkinje cells from below by the expanding granular layer and the barrier formed above these cells by the pile of the parallel fibres.

In the present normal newborns, at day 21 , the main dendrite of Purkinje cells arises from the upper end of the perikaryon and extends through the molecular layer and repeatedly branch to form large dendritic arborizations. Similar results were recorded in humans by Krause and Cutts (1994) and in rats by Bahgat et al. (2005).

This study showed that Purkinje cells were arranged in more than one row in the treated groups at days 7 and at D21 due to the late migration of these cells. These results are in agreement with Saleh et al. (1993). Thomas et al. (1998) reported that alcohol-induced Purkinje cells loss depends on the duration of alcohol exposure. Therefore, there is variability in the rate of Purkinje cells loss in these treated groups where the high number was in group B detected by light microscopical studies. Alcohol metabolism in the cytoplasm leads to acidosis, which affect the cell functions (El-Raghy, 1993). In groups C, D and $E$, Purkinje cells loss took place due to prenatal alcohol exposure (Griffin et al., 1977). In group E, Purkinje cells loss occurred in postnatal, because of chronic alcohol administration during the lactation. The aforementioned result was supported by detection of pyknotic Purkinje cells in groups B, C and E at day 21 . The high loss of Purkinje cells was represented by wide distances between Purkinje cells. The arborizations of Purkinje cells in groups $B$ and $C$, were reduced in most cells. Malnutrition reduced the size of arborizations (Griffin et al., 1977). Alcohol has indirect effect on cell dendrites as it impairs the placenta and the mammary glands functions, so it leads to fetus malnutrition (Luke, 1990; Luisa et al., 2001).

The intensity of Nissl granules in the neurons refers to the high metabolic activity of these neurons (Stevens and Lowe, 1997). The present study showed normal intensity of Nissl granules in the normal Purkinje cells. These evidences are in agreement with Stevens and Lowe (1997) who found the newborns of humans with high metabolic activity. In group B, many neurons were degenerated. In group C, most neurons were palestained, while moderately-stained in groups $D$ and $E$. According to the present results, it could be suggested that, in treated newborns the amount of Nissl granules were less than that in the normal ones. This result is in 
agreement with Heaton et al. (2000) who mentioned that alcohol causes disturbance in the metabolism and leads to cell dysfunction. Alcohol impaired cell metabolism (Hu et al., 1995) and led to protein deficiency (Luke, 1990); so the intensity of Nissl granules was low in the treated groups.

\section{ACKNOWLEDGEMENT}

This project was supported by King Saud University, Deanship of Scientific Research, College of Science Research Center.

\section{REFERENCES}

Altman J, Winfree AT (1977). Postnatal development of the cerebellar cortex in the rat. V. Spatial organization of the Purkinje cells perikarya. J. Comp. Neurol. 171:1-16.

Bahgat M, Ahmed OM, Nada MM, Ahmed RG (2005). Does the heat stress deteriorate the neurons development in albino rat newborn?. J. Egypt. Ger. Soc. Zool. 47:93-116.

Behave SV, Hoffman PL (1997). Ethanol promotes apoptosis in cerebellar granule cells by inhibiting the trophic effect of NMDA. J. Neurochem. 68:578-586.

Bondok AA, EL-Mohandes EA, Uthman ME (1991). Postnatal development of the rat cerebellar cortex. Experimental delay in the normal postnatal maturation. Egypt. J. Histol. 14(1):221-233.

Bonthius DJ, Bonthius NE, Napper RA, West JR (1992). Early postnatal alcohol exposure acutely and permanently reduces the number of granule cells and mitral cells in the rat olfactory bulb: A stereological study. J. Comp. Neurol. 324:557-566.

Clarren SK, Alvord EC, Sami SM, Streissguth AP, Smith DW (1978). Brain malformations related to prenatal exposure to ethanol. J. Pediatr. 92:64-67.

Coles CD, Brown RT, Smith IE, Platzman KA, Erickson S, Falek A (1991). Effect of prenatal alcohol exposure at school age: I. Physical and cognitive development. Neurobehav. Teratol. 13:1-11.

El-Raghy WE (1993). Histochemical Investigations of the Physiologic Effect of Alcohol Intoxication in Hyperglycemic Rats. Ph. D. Thesis, Faculty of Science, Mansoura University, Egypt.

Ernhart CB, Wolf AW, Linn PL, Sokol RJ, Filipovich HF (1985). Alcoholrelated birth defects: Syndromal anomalies, intrauterine growth retardation and neonatal behavioral assessment. Clin. Exp. Res. 9:447-455

Fitzgerald DM, Charness ME, Leite-Morris KA, Chen S (2011). Effects of ethanol and NAP on cerebellar expression of the neural cell adhesion molecule L1. PLoS One 6(9):e24364.

Griffin W, Sue T, Donold JW, Rita C (1977). Malnutrition induces alterations of developing Purkinje cells. Exp. Neurol. 56:298-311.

Hankin J, McCaul ME, Heussner J (2000). Pregnant alcohol-abusing women. Alcoholism: Clin. Exp. Res. 24:1276-1286.

Heaton MB, Mitchell JJ, Paiva M (2000). Amelioration of ethanolinduced neurotoxicity in the neonatal rat central nervous system by antioxidant therapy. Alcoholism: Clin. Exp. Res. 24:512-518.

Heaton MB, Paiva M, Kubovic S, Kotler A, Rogozinski J, Swanson E, Madorsky V, Posados M (2012). Differential effects of ethanol on Cjun N-terminal kinase, 14-3-3 proteins, and Bax in postnatal day 4 and postnatal day 7 rat cerebellum. Brain Res. 13; 1432:15-27

Hill SY, Wang S, Carter H, Tessner K, Holmes B, McDermott M, Zezza N, Stiffler S (2011). Cerebellum volume in high-risk offspring from multiplex alcohol dependence families: association with allelic variation in GABRA2 and BDNF. Psychiatry Res. 194(3):304-313.

Hu I, Singh SP, Snyder AK (1995). Effects of ethanol on glucose transporter expression in cultured hippocampal neurons. Alcoholism: Clin. Exp. Res. 19:1398-1402.

Huang C, Titus JA, Bell RL, Kapros T, Chen J, Huang R (2012). A Mouse Model for Adolescent Alcohol Abuse: Stunted Growth and
Effects in Brain. Alcohol Clin. Exp. Res. 36(10):1728-37

Idrus NM, Napper RM (2012). Acute and Long-Term Purkinje Cell Loss Following a Single Ethanol Binge During the Early Third Trimester Equivalent in the Rat. 36(8):1365-73.

lqbal U, Dringenberg HC, BrienJ F, Reynolds JN (2004). Chronic prenatal ethanol exposure alters hippocampal GABAA receptors and impairs spatial learning in the guinea pig. Behav. Brain Res. 150:117125.

Jones KL, Smith DW (1973). Recognition of fetal alcohol syndrome in early infancy. Lancet 2:999-1001.

Krause WJ, Cutts JH (1994). Essentials of Histology. Little Brown and Company, London.

Ludena MC, Mena MA, Salinas M, Herrera E (1983). Effect of alcohol ingestion in the pregnant rat on daily food intake, offspring growth, and metabolic parameters. Gen. Pharmacol. 14:327-332.

Luisa MF, Artillo R, Carreras O, Murillo ML (2001). Effects of maternal chronic alcohol administration in the rat: Lactation performance and pups growth. Eur. J. Nutr. 40:147-154

Luke B (1990). The metabolic basis of the fetal alcohol syndrome. Int. J. Fertil 35(6):333-337

Maier SE, West JR (2001). Regional differences in cell loss associated with binge-like alcohol exposure during the first two trimester's equivalent in the rat. Alcohol 23:49-57.

Maier SE, West JR (2003). Alcohol and nutritional control treatments during neurogenesis in rat brain reduced total neuron number in locus coeruleus, but not in cerebellum or inferior olive. Alcohol 30:6774.

Maier SE, Miller JA, West JR (1997). Prenatal binge-like alcohol exposure in the rat results in region-specific deficits in brain growth Neurotoxicol. Teratol. 21:285-291.

Marcelo RS, Fahad S (2002). The cerebellum at birth in therian mammals, with special reference to rodents. Brain Behav. 59:101113.

Miller MW (1996). Limited ethanol exposure selectively alters the proliferation of precursor cells in the cerebral cortex. Alcoholism: Clin. Exp. Res. 20:139-143.

Reneau J, Reyland ME, Popp RL (2011). Acute ethanol exposure prevents PMA-mediated augmentation of $\mathrm{N}$-methyl-D-aspartate receptor function in primary cultured cerebellar granule cells. Alcohol. 45(6):595-605

Richardson GA, Day NL, Goldschmidt L (1995). prenatal alcohol marijuana and tobacco use: infant mental and motor development. Neurotoxicol. Teratol. 17:479-487.

Saleh MN, Saleh MM, Desouky MA, Sayed SR, Saber EA (1993). Effect of alcohol on the postnatal development of cerebellar cortex in rat. I. Histological and morphometric studies. Assiut Vet. Med. J. 30(59):1131.

Saleh MN, Saleh MM, Desouky MA, Sayed SR, Saber EA (1995). Effect of alcohol on postnatal development of white matter of the cerebellum of the rat. Assiut Vet. Med. J. 32(64):1-15.

Sandra MM, Michael WM (2003). Ethanol induced neuronal death in organotypic cultures of rat cerebral cortex. Dev. Brain Res. 147:135141.

Stevens A, Lowe J (1997). Human Histology, 2nd Ed. Grafos, SA, Arte Sobre Papel, Madred.

Sulik KK (2005). Genesis of alcohol-induced craniofacial dysmorphism. Exp. Biol. Med. 230(6):366-375.

Spottiswoode BS, Meintjes EM, Anderson AW, Molteno CD, Stanton ME, Dodge NC, Gore JC, Peterson BS, Jacobson JL, Jacobson SW (2011). Diffusion tensor imaging of the cerebellum and eyeblink conditioning in fetal alcohol spectrum disorder. Alcohol Clin. Exp. Res. 35(12):2174-83.

Tavares MA, Paula-Barbosa MM (1986). Alcohol-induce granule cell loss in the cerebellar cortex of the adult rat. Exp. Neurol. 78:574-582.

Tavares E, Gomez-Tubio A, Murillo ML, Carreras O (1999). Folic acid intestinal absorption in newborn rats at 21 day postpartum: effects of maternal ethanol consumption. Life Sci. 64:2001-2010 .

Thomas JD, Goodlett CR, West JR (1998). Alcohol-induced Purkinje cell loss depends on developmental timing of alcohol exposure and correlates with motor performance. Dev. Brain Res. 105:159-166.

Tombol T (1966). Short neurons and their synaptic relations in the specific thalamic nuclei. Brain Res. 4:97-113. 
West JR, Parnell SE, Chen WJA, Cudd TA (2001). Alcohol-mediated Purkinje cell loss in the absence of hypoxemia during the third trimester in an ovine model system. Alcoholism: Clin. Exp. Res. 25 (7):1051-1057. 